\title{
Potências Imagéticas: Experimentações Clínicas e Dançantes
}

\section{Potencies Imagetic: Clinical Trials and Dancing}

\begin{abstract}
Resumo: $O$ artigo discute a imagem dançada como um dispositivo para novos contornos no corpo em sofrimento. Desse modo, cartografamos o Ballet Contágio, um grupo de dança contemporânea composto por usuários de um CAPS. Propomos uma clínica que aposta na produção da diferença para um coletivo que deseja ser atravessado pelas forças da experiência estética. Acompanhamos as transformações dos usuários do CAPS, que se tornam bailarinos e produzem novas potências imagéticas por meio de suas experimentações. Por meio da discussão de Gilles Deleuze, diferenciamos a imagem-movimento e a imagem-tempo, a fim de pensar em suas coexistências e maquinações. Ainda, questionamos como a dança contemporânea e a imagem fotografada podem servir como disparadores de ampliação da imagem-clichê para um contra-contorno de si, ou seja, em direção às virtualidades da imagem, que se transforma em uma nova estética. Desse modo, problematizamos tais questões no Ballet Contágio e seus efeitos na subjetivação. Palavras-chave: Potência Imagética. Ballet Contágio. Imagem-Tempo. Devir. Clínica.
\end{abstract}

Abstract: The article discusses the image danced as a device to a new shape in the body in pain. Thus, mapping the Contagion Ballet, a contemporary dance group composed of users of a CAPS. We propose a clinic that focuses on production of difference to a collective that wants to be traversed by the forces of aesthetic experience. We follow the changes of the users of CAPS, who become dancers and produce new imagistic powers through their experiences. Through discussion of Gilles Deleuze, we differentiate the image-motion and time-image in order to think about coexistence and their machinations. Still, we question how contemporary dance and the photographed image can serve as triggers stereotypical image magnification for a countercontour of each other, in other words, toward the virtues of the image, which becomes a new aesthetic. Thus, we discuss these issues in Contagion Ballet and its effects on subjectivity.

Keywords: Imagistic Power. Contagion Ballet. Time-image. Becoming. Clinic.

MOEHLECKE, Vilene; FONSECA, Tania Mara Galli. Potências Imagéticas: experimentações clínicas e dançantes. Informática na Educação: teoria e prática, Porto Alegre, v. 17, n. 1, p. 19-33, jan./jun. 2014.
Vilene Moehlecke

Universidade do Vale do Rio dos Sinos

Tania Mara Galli Fonseca

Universidade Federal do Rio Grande do Sul

\section{Fabulações}

U ma imagem qualquer dança diante dos olhos. Faz o corpo acompanhar seus riscos e piruetas. A atenção admira suas maquinações. Um jogo sinuoso faz proliferar mistérios e multiplicidades. Um movimento se torna intensivo, enquanto brinca com velocidades e lentidões. Não há como não se deixar contagiar perante tamanho arrebatamento. Por onde adentrar por entre suas fissuras e percalços? Vivemos os ecos da mesma questão replicada em várias. De que maneira a experimentação estética invade o corpo e faz de uma imagem comum a base para uma pequena máquina de contra-contornos, fragmento mínimo de um instante qualquer, envolta em potência e devir?

Deleuze e Guattari (1992) salientam que a obra de arte consiste em um monumento, que não comemora um passado, pois se torna um 
bloco de sensações presentes que só devem a si mesmas sua própria conservação. Elas dão ao acontecimento o composto que o celebra. $O$ ato do monumento, portanto, não é a memória, mas a fabulação. Nesse sentido, desejamos buscar fragmentos de memórias e imagens perdidas, para produzirmos novos sentidos a uma experimentação envolvente. $\mathrm{E}$, ao mesmo tempo, lançamos suas lembranças ao devir, para dar a ver novas composições imagéticas a tais desdobramentos. E, se o passado não existe, o que há são virtualidades do passado em nós. A pergunta não é mais: o que é isso, mas o que se passa? De que modo os cacos mnemônicos de um passado por vir invadem o vivido e nos fazem tremer as histórias? Então, de que maneira tentamos lembrar e também esquecer, a fim de compor uma pequena narrativa sonhada e problematizada para uma vida em sua coletividade e força de diferenciação?

Mergulhamos nas superfícies e nos vazios das lembranças em devir. Ainda podemos sentir a lentidão dos movimentos daquela pele. Um olhar perdido parece avistar o vazio e deixar-se sucumbir frente à sensação de inacabamento. Uma vida após uma crise, ou permeada por ela, expressa o inexpressivo, enquanto se deixa levar por um murmúrio inaudível, como se já não houvesse nada a fazer, ou a pensar. Um coletivo de enredos embebidos em sofrimento e invisibilidade atormenta um destino. O corpo se encontra roubado, desertado, levado às minúcias de uma lamentação perdida. $O$ silêncio é quase assustador, ao mesmo tempo em que uma certeza traiçoeira invade a face, tal qual a ideia de que o mundo pode devorar o pouco que resta de nitidez.

Assim, vive um ente atormentado pelas orgias da loucura. E, frente a um turbilhão de assombrações e temores, o corpo pára e se envolve no peso de uma desterritorialização qua- se contínua. Parece não haver saídas. A dor explora suas forças. Uma vida em crise assola a nossa ilusão de tranquilidade. Um corpo é roubado de seu próprio estilo. Já não falam de uma individualidade, mas de um coletivo em fúria, disfarçado no olhar que se perde frente às paisagens urbanas e frenéticas. A pele sente o cheiro do asfalto, acolhe o barulho dos carros apressados, mas mantém-se perdida em meio a tanta pressa. Uma vida sente-se estranha a seus conterrâneos, como se o passado já não mais lhe pertencesse, apenas o eterno presente, cronos ligado a um corpo em sofrimento e temor da destruição.

Nesse sentido, Deleuze (1997) coloca que a neurose e a psicose não são passagens de vida, mas estados em que se cai quando o processo é interrompido, impedido. A doença, nesse caso, não é processo, mas parada do processo. Prende-se uma vida em suas queixas, em seus modos de invenção e plasticidade. Aprisiona-se seu destino, como se ele estivesse fadado a repetir o inacabamento e a sofrer com o medo do afundamento sem volta.

Nesse caso, as antigas lógicas que excluíam a loucura já não servem, porque elas apenas a aprisionavam ainda mais. Podemos, então, desinstitucionalizar suas dores e apostar em uma clínica que reinvente sabores e permeie novas escutas para uma pele arrepiada pelo frio do abandono. Mais do que acolher seus desvios, desejamos cartografar suas façanhas e produzir, por meio de um encontro híbrido, novas expressividades ao corpo e suas produções imagéticas.

\section{Cápsulas de sonhos}

Sujeitos perdidos na correria da cidade, muitas vezes esquecidos pelas amarguras do 
capitalistmo, caminham sem rumo, ou permanecem sozinhos em suas casas. Nesse sentido, podemos pensar o quanto é preciso avançar em relação aos propósitos da Reforma Psiquiátrica e da Luta Antimanicomial, no sentido de desinstitucionalizar a loucura e reafirmar as políticas públicas em saúde mental, que assegurem um modo mais efetivo de cuidado ao sujeito em sofrimento psíquico.

Fonseca (2007) coloca a Reforma Psiquiátrica como múltipla, ao longo de seu plano de existência, transiente e a-subjetivada em maiores doses do que somos levados a supor. Pode agir sobre si mesma para, então, fazer existir as virtualidades que lhe são imanentes. Nesse caso, não falamos apenas de aplicação de diretrizes, porque viabilizar suas propostas consiste em lançar os seus discursos ao virtual, a uma atmosfera múltipla que pode se atualizar em diversos contextos, de acordo com as possibilidades e potências presentes.

Desse modo, os CAPS são criados para substituir os antigos hospitais psiquiátricos e para comporem uma nova rede de serviços, com uma concepção de um trabalho psicossocial ampliado. Eles foram se espalhando pelo país, ao proporem novas concepções de sujeito e de saúde, além de buscarem uma intervenção permeada pela promoção de vida. Enquanto cápsulas, eles se abrem e se fecham, aliviam tensões e experimentam outros fazeres. Condensam novas práticas, ou refazem antigas rotinas. Experimentam o novo, arriscam-se e, sem querer, reproduzem antigas lógicas, ao coisificar o sujeito e deixá-lo também esquecido nas malhas de seus muros, agora menores que os de outrora.

Segundo Yasui (2007), a Reforma Psiquiátrica firma-se, nos anos 80 , como movimento social, articulando usuários e familiares e inventando novas instituições e outras formas de produzir o cuidado em saúde mental. Ela se consolida nos anos 90, e no início do século XXI, como uma política pública nacional. Há, então, uma sustentação de suas propostas, no momento em que a reforma se mantém como modelo de trabalho e gestão a ser buscado. Há uma oficialização de suas condutas, por meio de leis, princípios e diretrizes, importantes para a busca de sua implementação e para a gradativa substituição do modelo anterior. Muitos são os investimentos nesse sentido, de trabalhadores, gestores e usuários do sistema único de saúde.

Assim, apesar das dificuldades encontradas, é possível abrir-se ao novo, além de propor uma clínica que amplie sua potência e aposte na produção de novas expressividades para uma vida em sofrimento. Nesse caso, um serviço se torna acolhedor da diferença, ou produtor de novos modos de agir e sentir a vida que se refaz e ultrapassa antigas ruminações. Tal qual uma pequena casa, acolhedora por limites inventivos e cores vivas, uma cápsula pode abraçar o olhar perdido de um sujeito que sofre, com o intuito de apoiá-lo e de convidá-lo a experimentar novos modos de ser e de sentir o mundo que se refaz de múltiplos modos.

Em nossas maquinações, construímos dispositivos para produzir um bom encontro entre uma cápsula de saúde e um corpo em sofrimento. Uma escuta atenta e ativa pode se tornar uma boa aliada para a construção de novas potências clínicas, abertas a novas tecnologias e expressividades. Nesse aspecto, propomos que a dança contemporânea sirva de disparadora para novos propósitos na clínica e na arte enquanto nova composição ético-estética. Apostamos na imagem fotografada como uma possibilidade de extrairmos contornos singulares de um corpo coletivo, que vibra com as singularidades agenciadas por meio da dança 
e suas vicissitudes. Portanto, convidamos o CAPS a dançar e vamos, pouco a pouco, cartografando um plano maquínico de aventuras e hibridações. Imagens de um tempo passado se misturam a um por vir revolvido em expectativas e sonhos.

Em nossas experimentações, nasce, devagarinho, o Ballet Contágio, um grupo de dança contemporânea composto por usuários de um CAPS. Desse modo, a arte se torna um dispositivo para a expressão de novos modos de ser, bem como para a composição de uma grupalidade singular. Um corpo aprende com o outro, ambos se misturam a uma atmosfera envolta em músicas, ensaios e palavras inventadas. As imagens fotografadas do grupo, dos ensaios e apresentações também fazem parte de pequena história, que passa a ser cartografada pelos integrantes de um ballet cheio de vida e de desejo por novas expressividades.

O que podemos esperar dessa pequena coletividade? Em que consistem seus embates e multiplicidades? Quais as potências das imagens fotografadas e dançantes? Como vemos o mundo por meio desse acoplamento artístico e envolvente? Adentramos caminhos, reviramos antigas lógicas, ao apostar em um movimento ético-estético, que encharca o corpo com novas proposições e intensifica suas potências.

Deleuze (2008) salienta a questão de Spinoza, o qual se questiona o que pode um corpo? Como um corpo pode aumentar as suas potências? Nesse sentido, as escolhas definem o que convém e o que não convém. Isso pode configurar um novo modo de existência. Nesse caso, um corpo não se define por formas ou funções, mas como uma relação complexa entre velocidades diferenciais. Trata-se, pois, de uma composição de velocidades e lentidões num plano de imanência. Nesse caso, nunca se começa nada, desliza-se entre. Um corpo se abre para aquilo que Ihe convém e também interfere em tal jogo. Ele afeta e é afetável, por meio dos encontros que agencia. Ninguém sabe, antecipadamente, os afetos de que é capaz. Perguntamos, então, o que pode uma imagem dançante? O que suas formas móveis e fluidas podem produzir nos corpo coletivo que experimenta as aventuras do dançar? Questionamos, assim, quais as forças que atravessam o Ballet Contágio, no sentido de expandir a potência de agir de seu corpo e suas multiplicidades imagéticas?

\section{Há devir na imagem?}

Deleuze (2008), ao lembrar Spinoza, salienta que um corpo é definido pelos afetos de que ele é capaz. Em um movimento ético, ocorre uma composição de velocidades e lentidões, dos poderes de afetar e de ser afetado em um plano de imanência. Perguntamo-nos, pois, como compor as potências, as velocidades e as lentidões? Ou, no caso mais específico de nosso grupo, de que modo apostar em um bom encontro entre linguagem dançada e corpo em sofrimento? $\mathrm{E}$, nesse caso, quais os afetos dos quais um modo bailarino é capaz? E como a imagem dançada pode tensionar ainda mais tais proliferações?

Por meio de nossos ensaios e experimentações, um corpo lentificado, desertado de sua alma, se deixa envolver com o Ballet Contágio. O grupo se reúne há quatro anos. Já sofreu perdas e desvios, alegrias e plasticidades. Contagiamo-nos com as desmesuras e as conquistas dos personagens de nossos enredos envolventes. Um personagem coletivo deixa-se contaminar pelas alegrias das imagens dançantes. E, se outrora viveu uma sensação de despotência, pode, então, arriscar-se em no- 
vas forças. A imagem que nos chega é pulverizada, esvaziada, cinza. Parece não haver cores em uma vida embebida pelo sofrimento da psicose. A dor é tão grande, que prefere não se manifestar, apenas prende a pele à sua própria condição de incapaz. Assim, chegam os corpos que querem dançar, parecidos com vultos, ou sombras mortificadas. E, gradativamente, por meio de incontáveis ensaios e encontros, um corpo pode ser capaz de experimentar as forças do dançar, ao deparar-se com a própria imagem refletida na foto, transformada em contra-contorno de si, exposta a uma nova envergadura. Uma quase invisibilidade produz novas tonalidades, se deixa levar pelos ritmos de uma música suave e contagiante, arrisca-se a desejar as próprias alterações. Um sorriso no canto dos lábios expressa que o sonho torna-se linguagem estética de um tempo bifurcado em instantes inventivos.

Para Deleuze e Guattari (1997), o devir implica em uma involução, em que a forma não pára de ser dissolvida, para liberar tempos e velocidades. Não se trata de imitação, ou identificação. O devir implica, então, a possibilidade de, a partir das formas que se tem, do sujeito que se é, extrair partículas, através de relações de movimento e repouso, de velocidade e lentidão, as mais próximas daquilo que estamos em via de nos tornarmos. Ele indica o movimento do desejo, além de uma zona de vizinhança ou de co-presença de uma partícula.

Nas experimentações do Ballet Contágio, presenciamos a fabricação de uma nova textura para a imagem louca, agora não mais atrelada à incapacidade, porém exposta a outra vibração - a potencialidade de sonhar, de arriscar-se em novos gestos dançantes. O olhar do corpo que sofre pode sentir outra intensidade, não somente a do mundo que o ameaça, mas a da vida que pulsa por múltiplos lados e o faz esquecer as antigas lamentações e abandonos. Nasce, aos poucos, um desejo de ser visto pelo olho do outro, no sentido de deixar-se tocar pela admiração e pela aposta de uma diferença produzida por meio da atmosfera dançante e imagética.

Em nossas cápsulas de sonhos, imagens acinzentadas deliram frente a músicas inétidas, desejam a própria expansão e anseiam por instantes de multiplicidade. Uma imagem-clichê, reprodutora de uma loucura informe e abandonada, encontra-se com o seus devires, abre-se ao caos e se deixa conduzir por um novo estranhamento. Nos nossos contágios, corpos dançam e constroem híbridos entre os limites desterritorializados e as potências de uma imagem por vir, envolvida em novas composições e levezas.

Acompanhamos, atentos, tais maquinações e delírios imagéticos, para darmos maior consistências a tais investimentos. Em meio a tal trama, Deleuze (1983) diferencia o reconhecimento automático do reconhecimento atento. O primeiro está ligado à imagem sensório-motora e, tal qual uma descrição, escolhe certos traços da coisa, de um modo provisório. Vemos o jogo do evidente, do demonstrável, do que está ali. Nesse caso, o conceito não gira, fica parado no mesmo lugar. Por meio da imagem sensório-motora, há uma associação da coisa por outras que se parecem com ela no mesmo plano. Podemos olhar, pois, para os corpos da psicose e reconhecê-los naquilo que já são, ou que já vimos, os seus tormentos, sintomas e estereotipias. Olhamos, então, para o que eles não podem, bem como para suas impossibilidades e tormentos. Nesse caso, a loucura permanece associada à incapacidade. Reproduzimos uma prática baseada em antigas lógicas e clichês, disposta a tornar a rotina da exclusão e do estigma o seu lema principal. 
No CAPS, contudo, uma sombra parece envolvida por obscuridades e contornos imprevisíveis. Em tal inacabamento, presenciamos suas potências e forças de transformação. Frente ao estereótipo de fracasso, um corpo expressa suas vontades e potências, seus limites se estendem e podem compor uma nova suavidade. Assim, quando Deleuze (1983) aborda o reconhecimento atento, este surge como uma possibilidade de extrairmos contornos singulares do objeto. Em meio a tal disparação, produzimos uma imagem ótica e sonora pura. A raridade do que detém, como um fragmento mínimo sem importância, elevam a coisa a uma singularidade essencial, pois descrevem o inesgotável.

No Ballet Contágio, por meio da dança e da imagem estética, apostamos no movimento e em suas intensidades, não apenas para subordinar o vivido a uma mera descrição que a ligasse ao já conhecido, mas para ampliar as potências e perspectivas. Nos nossos pequenos ballets cotidianos, tentamos extrair um contorno singular para o sujeito em sofrimento. E, de pacientes a bailarinos, uma vida pulsa de novos modos e experimenta vibrações. Em meio a um bailado de ensaios e encontros, investimos em suas proliferações e descobertas. A atenção pousa sobre aquilo que nos afeta e transforma. Os sentidos pulsam em meio a novas vibrações e compõem, com o corpo, maquinações que se aproximam e se afastam, ao provocarem novas intensificações para a experiência estética.

Vivemos, então, uma coexistência das imagens, naquilo que as sucubem, mas também no ponto em que as fazem ultrapassar antigos queixumes. Uma sombra se põe a dançar, ao mesmo tempo em que um gesto quase invisível vai tomando uma nova consistência, ganhando uma forma singular. A imagem-clichê parece, pois, revolvida, misturada em si, para ser atravessada por acontecimentos dançantes. Seus contornos se dissipam e promovem novas conexões. Híbridos entre som e pele, corpo e movimento, invisibilidade e energia aparecem como personagens dessa nova atmosfera que vai sendo tecida a cada encontro. Formas afundadas numa caótica de dramas e aprisionamentos sobem à superfície dançante. Algo convoca o corpo eticamente para operar a diferenciação. Um personagem se depara com suas virtualidades dançantes, ao olhar a fotografia dos ballets contagiantes. Seus olhos disparam uma nova sensação, como se o encontro entre as cores fotografadas e os cheiros do corpo produzissem uma nova alegria.

Nesse jogo de contornos inventamos, Vilela (2010) discorre sobre a importância da imagem fotográfica, que não reside na representação, tampouco na narrativa de um fato, e sim, na ruptura de uma ordem discursiva. Numa imagem produzida, os corpos resistem e se colocam como um gesto que rasga o olhar. No Ballet Contágio, temos a possibilidade de romper com os discursos que retratam a loucura em sua incapacidade e isolamento, a fim de investir em novas linguagens, entre a dança e a imagem, que passam a pensá-la como uma usina criativa de expressões singulares. Não se trata de querer representar um movimento ou uma ação artística, e sim, de relançar o corpo a incontáveis multiplicações e contornos estendidos. O que vemos nas imagens nos leva a perspectivar uma vida em suas surpreendentes chances de expansão e de energia.

Se o devir não informa, mas deforma o próprio contorno, ao abrir o corpo para novas maquinações, brincamos com tais investimentos e trabalhamos para a sua sustentação. O olho encontra a foto e um não muda menos que o outro, pois ambos se alteram e vivem os riscos 
de tal contaminação. A pele dança com a música, as duas vivem as peraltices de se adentrarem uma na outra, enquanto promovem uma co-presença, tal qual uma imagem avizinhada, que as fazem diluir contornos e suscitar novas dramatizações. Os integrantes do Ballet Contágio se tornam, desse modo, pequenos artesãos da multiplicidade desse mundo finito fazendo devir.

\section{Ballet Contágio: imagem e afec- ção}

Pensamos, pois, em imagens-clichês, cujo papel consiste em apenas reproduzir modos de relação e de expressão do mesmo. Um modo-contorno, preso em si, permanece a explorar os repetidos caminhos, com as vozes de outro$\mathrm{ra}$, sem poder criar novos sentidos. As cores se fixam em uma única monotonia, como se não fosse mais possível sonhar com hibridações e imprevisibilidades. Nesse caso, como podemos romper com tais estereótipos? No Ballet Contágio, os pacientes exibem incontáveis imagens-clichês. Vemos, muitas vezes, um modelo de loucura e de doença, assim como um protótipo de relação entre o técnico do serviço e seus usuários. Assistimos a uma clínica enfadonha, que repete estigmas e auxilia para a manutenção dos mesmos. Percorremos reproduções aprisionantes, pois temos medo do novo e do que ele é capaz de despertar.

O que somos capazes de inventar, para romper com o mesmo e apostarmos em uma intervenção híbrida e potencializadora? Nesse caso, o Ballet Contágio surge como um caminho dentre muitos outros, a fim de dar a ver atualizações na clínica. Pode, então, a dança e as imagens nos auxiliar a rompermos com tais enclausuramentos? De que o devir da ima- gem é capaz? O que produz de efeitos no corpo dançante e na subjetivação? Assim, operamos com a produção de imagens instituintes, que rompam com tais determinações e acionem novos olhares e perspectivas. Encontramos, nos corpos que dançam, a matéria-prima para a transformação da mera execução de ações em um leque de gestos estéticos e dispostos a deslizar na imanência de uma vida envolta em multiplicidade.

Conforme Deleuze (1983), o dançarino, a subjetividade, passa de uma motricidade pessoal a um elemento suprapessoal, a um movimento de mundo, que a dança vai traçar. Nos nossos ensaios, o grupo dançante experimenta a diferença e a repetição, por meio das coreografias inventadas e de seus efeitos sobre o corpo que inventa e se expressa de novos modos. Entre o passo motor e o passo de dança, há um 'grau zero', como uma hesitação, um atraso, uma série de falhas preparatórias. Nesse sentido, os devires imagéticos são produzidos por meio de um trabalho estético, o qual permite que o corpo produza um movimento impessoal, ligado ao fora e reconfigurado a partir de suas potências e imbricações.

Para o autor (op. cit.), a dança pode garantir a transição da vista chapada à abertura do espaço. Será ele, o movimento de mundo que corresponde, no sonho, à imagem ótica e sonora. Cartografamos, assim, a expansão do clichê em novos contornos e permeabilidades. A dança não dá apenas um mundo fluido às imagens, pois há tantos mundos quanto imagens. Ela já não é apenas movimento de mundo, mas passagem de um mundo a outro, entrada em outro mundo. Portanto, um corpo adoecido é capaz de adentrar em um mundo estético e imagético, intensivo e envolto e simultaneidades. Acompanhar suas trajetórias complexas se torna uma tarefa envolvente e cheia de surpresas. Apostar em suas conquis- 
tas se torna a chama que nos move para novas produções e alegrias.

Portanto, um corpo, outrora roubado de sua alma, exposto ao caos, aprisionado em adoecimentos, se deixa envolver pelas potências do Ballet Contágio. Sua transformação passa a ser inevitável, bem como as potências de um vir a ser estético e inventivo, desprovido de memórias ressentidas. Se alguns integrantes não se tomam por tais aventuras e desistem, alguns outros permanecem no grupo e se deixam afetar pelas forças da dança e de suas produções fotografadas. Saboreamos, pois, as potências desdobradas em outras, que levam os integrantes bailarinos a gozar de uma aventura singular.

A propagação de uma melodia sinuosa e densa faz o corpo suar e desejar o próprio transbordamento. Uma dança coreográfica de ardores e saltos leva forças e informes a trocar passos entre a solidão e a vontade de ampliar a potência dançada. Com isso, Deleuze e Guattari (1992) argumentam que os afectos transbordam a força daqueles que são atravessados por eles. O afecto não é a passagem de um estado vivido a outro, mas o devir não humano do homem. Trata-se, pois, de todas as possibilidades do sentir, as variações da percepção. No grupo, o corpo dança e se percebe de outro modo, exposto às forças estéticas, mas também protegido pela própria coletividade dançante.

Em nosso Ballet, os contágios são múltiplos. Corpos em sofrimento tangenciam as experiências estéticas, ao se deixarem atravessar pelas afecções da arte dançante e da imagem inventiva. Passamos a perceber o mundo de outros modos, uma vez que corpo e subjetivação se abrem a novos devires. O que muda não é o sentir, mas o modo de sentir. Nesse aspecto, o objetivo da arte consiste em extrair um bloco de sensações, um puro ser de sensações. Para tanto, é preciso um método que varie com cada autor e que faça parte da obra. Nas experimentações do Ballet Contágio, extraímos sensações de um corpo que se arrisca em dançar, compomos um método associado aos acontecimentos que nos atravessam e nos fazem esquecer antigos limites.

\section{Circuitos imagéticos}

Quando um integrante do Ballet Contágio inventa novos passos, os demais acompanham, atentamente, seus riscos e vontades. Para Deleuze (1983), dois termos entram em relação na imagem ótica (e sonora) no reconhecimento atento. Trata-se, assim, de uma conexão entre real e imaginário, físico e mental, descrição e narração, atual e virtual. Os dois termos em relação tendem a se confundir, ao cair num mesmo ponto de indiscernibilidade. Desse modo, a coisa passa por uma infinidade de planos e circuitos. A outra descrição corresponderia uma nova imagem mental virtual: outro circuito. Elas exprimem séries heterogêneas de elementos em composição e desalinho, que permeiam devires e compõem novos acoplamentos.

Em nossas coreografias, os movimentos são inventados pelos integrantes do grupo. Os passos iniciais dos ensaios são compostos por esse pequeno coletivo. Um gesto qualquer pode ser transformado em gesto alongado, em aquecimento do porvir, ou, ainda, em peça importante para a próxima aventura coreografada. Por meio dessa questão, dois termos híbridos entram em relação, tal qual o encontro entre o movimento atual e o virtual, ou entre o passo motor e o movimento dançado. A imagem dança com o corpo e produz-se, de tal intensidade, uma nova atmosfera.

Portanto, cada circuito apaga e cria um objeto. Vivemos um duplo movimento de criação 
e apagamento, velocidade e lentidão. Hábitos os planos híbridos que suscitam uma nova envergadura clínica. Memórias e esquecimentos co-habitam os planos intensivos e espalham seus fragmentos reconfigurados. Nas experimentações estéticas, vemos os planos sucessivos, os circuitos independentes, se anulando, se contradizendo e se bifurcando. $O$ que nasce de tal maquinação se faz único, singular, como um mundo novo que se acopla a outro, enquanto produz desvios, multiplicidades e desejos sutis.

No momento em que o Ballet Contágio dança, desejamos, arduamente, o olhar atento do outro. Reconhecer-se, atentamente, envolve o próprio ato de se reinventar e de tecer uma nova melodia. O funcionamento da atenção se refere, pois, a cartografar e a criar de novo, não somente o objeto percebido, mas os sistemas aos quais ele pode se ligar. O corpo dançante exerce a potência de mapear os próprios dinamismos, no sentido de seguir seus mistérios e cumplicidades nômades. Nesse caso, um passo dançado se liga às suas sombras e imagens, adentra em esquecimentos e murmúrios, produz uma nova nitidez, ao mesmo tempo em que habita o seu contra-contorno, o limite expandido de seus devires e proliferações.

Segundo Deleuze (1983), a situação ótica e sonora é uma imagem atual, mas que, em vez de se prolongar em movimento, encadeia-se com uma imagem virtual e forma com ela um circuito. O tempo não é mais subordinado ao movimento, mas se desdobra em distintas temporalidades, abertas em desvios e perplexidades. E não são apenas os circuitos que se desdobram entre si, pois cada um deles se bifurca consigo mesmo, como um cabelo quebrado. Assim, as linhas se cortam e expandem em novas contaminações e agenciamentos.

Um corpo bailarino pode dançar as expressões de um novo si, enquanto se envolve com os esquecimentos daquilo que não é mais, e o reconhecimento atento frente ao que está se tornando. Ao ver-se na foto dançada, é capaz de reconhecer o próprio contorno inventado, enquanto revê a forma esquecida e replicada em novas composições dançantes. Assim, ele passa a narrar as pequenas aventuras dos contágios dançados e envolvidos com suas fabulações singulares.

Deleuze (1997) salienta a força da literatura, já que ela produz na língua uma espécie de linguagem estrangeira. Dessa maneira, não se trata de produzir outra língua, e sim um devir-outro da língua, uma minoração dessa língua maior, um delírio que a arrasta, uma linha de feitiçaria que foge ao sistema dominante. No caso do Ballet Contágio, não tratamos de criar uma dança nova, ou um novo lugar para a loucura. Simplesmente, convidamos o corpo a dançar, para fazer, desse encontro, um devir-outro da imagem dançada, tal qual uma pulsação singular de um contorno envolvido em novos sentidos e movimentos. E, se cada escritor é obrigado a fabricar para si a sua língua, como diz Deleuze (1997), e a língua é tomada por um delírio que a faz sair de seus próprios sulcos, podemos pensar que um corpo dançante se deixa agenciar por um novo delírio: a força do dançar. Ao experimentar o fora de si, é possível criar um novo dentro, estetizado, tocado por imagens em devir, que o faz reverberar afecções e virtualidades. E, assim, em meio a um trabalho coletivo e dançado, um novo circuito se produz, ao tecer uma nova costura entre corpo, dança e potência imagética.

\section{6 Ímãs e bifurcações}

Os integrantes do nosso grupo de dança parecem bastante envolvidos no ato de dançar. Desse modo, eles inventam passos novos, en- 
saiam a coreografia incontáveis vezes e buscam por novos locais de apresentação. Inicialmente, o medo de dançar era muito forte, bem como o temor da exposição. Pouco a pouco, e por meio de muitos encontros e experimentações, um somatório de sujeitos foi se transformando em uma coletividade disposta a dançar e a produzir imagens estéticas. Atualmente, a demanda pela arte merece destaque em nosso cotidiano dançante.

Podemos nos questionar, pois, o que ligam os corpos bailarinos no Ballet Contágio? De que maneira passamos a produzir o desejo pelo dançar, ou a demanda de um olhar que dispara o encontro com a fotografia dançada? Como os bailarinos se aproximam, entre trabalhos e ensaios, enquanto podem explorar o próprio inacabamento e apostar nas potências novas, que o fazem sucumbir frente aos movimentos de mundo? E como lidam com suas distâncias?

Para Deleuze (1983), os pontos de bifurcação são o mais das vezes tão imperceptíveis, que só podem revelar-se posteriormente, a uma memória atenta. Trata-se de uma história que só no passado pode ser contada. Pergunta-se: o que se passou? Acionamos o flash-back que rompe a causalidade e dispara o enigma, ao remeter a outros enigmas. Ao invés de uma resposta fechada, a pergunta se desdobra em novas indagações, o que leva a uma propagação de sentidos misturados. Assim, voltamos na história e, simultaneamente, produzimos um novo tempo, investido em suas virtualidades e mistérios. Indagamos, então, o que se passou com o Ballet Contágio, ao mesmo tempo em que as saídas para tal questão já transformam os significados anteriores.

Portanto, em vez de uma memória constituída, como função do passado, vemos o nascimento da memória como função do futuro que retém o que se passa para dele fazer o objeto por vir da outra memória. Nesse jogo de lembranças e esquecimentos, é possível extrair do tempo a singularidade de um instante perdido, a fim de dar a ver outras maquinações linguísticas para o empírico. Dessa maneira, experiência e linguagem se conectam e se bifurcam em agenciamentos coletivos de enunciação. O corpo se arrisca em constituir múltiplas vozes para os acontecimentos que o atravessam e o transformam.

Desse modo, no Ballet Contágio, a imagem fotografada dançante nos ajuda a produzir pequenas histórias do grupo, como um fragmento mnemônico que narra e, ao mesmo tempo, produz outras perspectivas para o visto e o vivido. No instante em que um integrante se encontra com a foto dançada, produz-se qualquer coisa de novo na atmosfera, que o faz ligar sensações e palavras àquela potência imagética. O que se passou naquele gesto estético? Uma pergunta aciona desvios na linguagem e faz o corpo se surpreender com as potências experimentadas.

As memórias, nesse caso, podem se ligar às virtualidades e invenções. Segundo Deleuze (1983), a imagem-lembrança não é virtual, ela atualiza por sua conta uma virtualidade. Ela não nos restitui o passado, mas traz o antigo presente que o passado foi. No Ballet Contágio, integrantes bailarinos recontam, incontáveis vezes, as suas dramáticas e histórias, ao mesmo tempo em que produzem sentidos singulares para as suas questões. Além disso, eles recriam valores e ações para o coletivo dançante, com o intuito de construir outras perspectivas para os anseios e desejos do grupo. Trata-se de um trabalho grupal que demanda uma atenção sensível aos micro-acontecimentos que permeiam as histórias e experiências vividas. Nesse caso, eles se reconhecem enquanto um coletivo de usuários de um serviço de saú- 
de mental, mas também como um grupo de bailarinos que deseja apenas seguir dançando e produzindo novas dramatizações estéticas.

Nesse sentido, o reconhecimento atento, quando tem êxito, se faz por meio de imagens-lembrança. E, nesse particular, ele nos informa muito mais quando fracassa do que quando tem êxito. Questionamos, pois, quais as memórias que precisam fracassar no CAPS, ou serem esquecidas, a fim de dar a ver novos olhares para a loucura e seus modos expressivos? No nosso ballet, apostamos, muitas vezes, nas fraquezas da memória queixosa, para compor um novo olhar sobre o sujeito dançante. Abrimos mão da lamentação e da reminiscência culpabilizadora, a fim de dar a ver novos propósitos ao corpo que dança e se deixa fotografar em suas aventuras estetizantes.

Para Deleuze (1983), nesse 'fracasso', a imagem atual entra em relação com elementos virtuais, fantasmas ou cenas de teatro. Portanto, em tal jogo envolvente, não é a imagem-lembrança, ou o reconhecimento atento que nos dá o correlato da imagem ótico-sonora, são antes as confusões de memória, os fracassos do reconhecimento. Salienta-se, assim, a teoria bergsoniana do sonho: os lençóis de passado fluidos e maleáveis com um ajuste bem frouxo e flutuante.

Nas experimentações do Ballet Contágio, é possível confundir antigos estereótipos e exclusões em relação à loucura, para fazer uso de outros olhares e novas formas de cuidado. Nesse caso, integrantes bailarinos se deixam envolver pelos véus da memória e do esquecimento, a fim de abrir mão de ruminações e apostar na força de um bom encontro. Tal gesto traz efeitos significativos na subjetivação, no sentido de um modo bailarino ousar em novos jeitos de existir, os quais trazem a plasticidade expressiva. Em nossas aventuras coreográfi- cas, os contornos se atraem e se repelem, ora diminuindo, ora expandindo a potência de agir do corpo e da imagem dançante.

\section{Imagens-contagiantes: o movi- mento se abre ao tempo}

Inicialmente, os movimentos em um grupo pareciam caóticos e presos em demasia à futilidade do cotidiano. Ora lentificados demais, ora desajeitados, a sensação era de que seria quase impossível transformá-los em dança. Pouco a pouco, e por meio de muitos encontros e ensaios, um corpo coletivo começa a se arriscar em relação aos próprios movimentos e vibra com as suas conquistas inéditas. A partir de suas expressividades singulares, vamos compondo um enredo permeado por afetos, resignificações e gestos em devir.

Com isso, podemos pensar a questão do tempo que se desprende do movimento. Deleuze (1990) salienta duas imagens: imagem-movimento e imagem-tempo. Na lógica da primeira, o tempo é concebido como sucessivo e obediente a uma organicidade e previsibilidade. Nesse sentido, está subordinado ao movimento, uma vez que aquele é a própria medida deste. Na imagem-movimento, há um espaço bem qualificado que supõe uma ação que o desvele, ou suscite uma reação que se adapte a ela ou a modifique - situações sensório-motoras. Isso significa dizer que, primeiramente, ocorre uma ação e, posteriormente, uma reação, que pode ser de adaptação à primeira ou de contestação àquela. Por isso, o tempo, na imagem-movimento, está subordinado às ações e respeita a um ordenamento da linearidade de Cronos.

Nesse particular, o corpo pode estar engajado nesse movimento, e, muitas vezes, ser 
composto por uma temporalidade sucessiva. As imagens, nesse caso, podem seguir modelos, tornarem-se clichês, como padrões de imagens a serem seguidos. Há, portanto, uma lógica das ações a ser respeitada. Ela produz imagens semelhantes, isto é, uma imagem sensório-motora da coisa. Ao produzirmos imagens clichês, percebemos parte da coisa, conforme nossos interesses, e a transformamos em algo parecido ao que já exista. Por esses motivos, entendemos que o corpo, na imagem-movimento, se faz a partir de um tempo linear e atual e busca a sua manutenção. No Ballet Contágio, o corpo dançante pode aprender certas modelagens, para, posteriormente, ser capaz de ultrapassá-los.

Entretanto, segundo Deleuze (1990), algo se dá para além da imagem-movimento e do seguimento dos modelos. Por mais que haja uma ação, por mais que o personagem se mova, a situação extravasa suas capacidades motoras por todos os lados e lhe possibilita ver e ouvir o que não é mais passível de ação. Trata-se da imagem-tempo, na qual o tempo não mais se subordina ao movimento, mas este se transforma na perspectiva daquele, na intensidade dos vazios, na complexidade do Impessoal. A imagem-tempo se faz a partir de encontros que provocam uma transformação de ambas as partes, em que um não muda menos que o outro, e os próprios objetos conquistam uma realidade material autônoma, que os fazem valer por si mesmos, sem a necessidade de uma ação, mas de um acontecimento, de um devir imperceptível. Isso significa dizer que, na imagem-tempo, qualquer coisa é passível de transformação, de passagem, independente de haver uma prática ou não. Mais do que uma ação, é fundamental haver o encontro, a irrupção de novos mundos e descobertas. Além disso, na imagem-tempo, o personagem está entregue a uma visão, mais do que engajado numa ação, já que a imagem não é mais somente sensório-motora, mas ótica e sonora, investida pelos sentidos, pelas potências do corpo, por uma nova sensibilidade e abertura.

Numa situação ótica e sonora, algo poderoso demais, ou injusto demais, ou belo demais pode exceder nossas capacidades sensório-motoras. Dessa forma, podemos romper com as imagens clichês da imagem-movimento e produzir novas imagens, com seus excessos e transbordamentos. E, paradoxalmente, isso pode ocorrer através de uma situação limite ou banal, cujo fundamento reside numa aposta maior do cotidiano como incentivador da invenção.

No Ballet Contágio, há um investimento do corpo, para que a imagem-movimento se quebre e deixe emergir situações ótico e sonoras, isto é, um corpo investido pelos sentidos, pelo acontecimento, por uma imagem-tempo. Em relação à ocupação do espaço, a imagem-tempo se estabelece no espaço qualquer, esvaziado, desconectado, diferentemente da imagem-movimento. O espaço vazio revela mudança marcada pela passagem, com novos modos de preenchimento. Há, pois, um ponto de indiscernibilidade, na imagem-tempo, entre objetivo e subjetivo, real e imaginário, visão e sensibilidade, vazio e diferença. Isso requer um tempo virtual, em que passado e futuro podem coexistir com a imagem presente. Se as duas imagens do tempo coexistem, a imagem-movimento não desaparece, mas passa a existir como a primeira dimensão de uma imagem que não pára de crescer em dimensões múltiplas, além de transportar-se de modos diversos.

Deleuze (1990) discorre sobre o movimento, nas duas imagens do tempo. Assim, os movimentos normais subordinam o tempo $\mathrm{e}$ 
atestam a presença da imagem-movimento. Já os movimentos aberrantes atestam uma anterioridade do tempo, o que não o denota como pré-estabelecido e fechado em a prioris, mas revela-o como abertura infinita, uma anterioridade a qualquer movimento normal, definido pela motricidade, anterior ao desenrolar regrado de qualquer ação, isto é, como tempo intensivo e não linear. São movimentos que se abrem ao acaso e às surpresas do encontro. Eles podem quebrar antigos modelos e propor outros. Ora, se assim ocorre, não consiste a imagem dançante numa eterna busca por movimentos aberrantes e descentrados, que contenham, em si, um caráter de insubordinação ao tempo linear, de quebra de atuais práticas motoras?

\section{Considerações finais}

Entendemos o quanto a dança contemporânea e a imagem fotografada servem de dispositivos para uma clínica que se abre ao devir em um CAPS. Nossas histórias foram sendo recontadas de múltiplos modos, a fim de produzir novos sentidos às experimentações estéticas e dançantes. E, gradativamente, por meio de encontros e ensaios, os usuários da cápsula de sonhos foram esquecendo antigas ruminações, que o ligavam à noção de uma loucura atrelada à incapacidade e à exclusão. Com isso, podemos apostar em um corpo em sofrimento que também se lança ao dançar e às imagens produzidas de um modo estético, para compor um novo enredo a um coletivo que se arrisca em novas singularidades e expressões. As dificuldades seguem havendo, como as distâncias entre integrantes, ou o medo da desistência, mas, simultaneamente, a produção da diferença se dá no cotidiano do grupo, o que faz com que a potência de dançar cresça a cada novo instante ensaiado. Isso faz com que a clínica seja permeada por uma nova aposta, a da estética ligada ao movimento inventivo de um grupo contagiante.

Nesse caso, o grupo pode fazer uso de um reconhecimento atento, na tentativa de extrair contornos singulares do gesto e da imagem, para recriar sentidos e movimentar as expressões de si. Um corpo coletivo produz novos circuitos, ao mesmo tempo em que promove bifurcações nos próprios contornos e estilos. Uma vida, outrora roubada de sua alma, esquecida pela cidade, passa a experimentar outros esquecimentos e novos usos de si, o que promove efeitos na subjetivação. Apostamos, pois, em um devir bailarino, que se contamina pelas conquistas produzidas em uma potência imagética dançante.

Ao dançar, no Ballet Contágio, falamos em imagem-movimento, mas também em imagem-tempo, assim como em riscos e certezas, ações e paradas. As belezas e os estranhamentos passam a co-habitar os contra-contornos agenciados nas nossas experimentações. Sabemos que o bailarino pode, simultaneamente, buscar uma ação a ser executada, isto é, uma imagem-movimento, mas também ele é capaz de descentrá-la e criar novas intensidades, tal qual uma imagem-tempo. Através desta, o bailarino não subordina o seu corpo unicamente a uma ação e pode atualizar outros corpos virtuais, para desprender-se dos antigos gestos.

Portanto, em nosso ballet contagiante, o corpo requer um tempo enquanto linearidade, em alguns momentos, quando é preciso dispor da imagem-movimento. Entretanto, tal ordem é simultaneamente quebrada, quando se compõe uma imagem-tempo, a qual se desprende das linearidades e se joga num tempo em devir. Nesse caso, um tempo sucessivo e subor- 
dinado ao movimento coexiste à imagem-tempo. Ele é capaz de se tornar paradoxal e se desprender do movimento. Podemos respeitar a sucessão dos passos, a seqüência da coreografia, entretanto, o corpo que dança também se joga na complexidade dos gestos e tenta incansavelmente ultrapassá-los, recriá-los em novos agenciamentos.

Desse modo, desprender o tempo do movimento, ou o corpo da ação, implica conectá-lo à sua dimensão virtual, a uma vida, ao Impessoal, a novas possibilidades estéticas. Nesse sentido, Uma Vida contém virtualidades, acontecimentos, singularidades, energias que circulam e aumentam a chance das metamorfoses. Conforme Deleuze (2002), o virtual não é algo a que falte realidade, mas que atualize potências. Ele é sem ser dado, como um contorno que existe sem ser fixo, algo indeterminado que faz o corpo mudar e o transporta a novos movimentos e passagens. Por isso, o plano de imanência é virtual, na medida em que os acontecimentos que o povoam são virtualidades. O virtual não está, portanto, inserido num domínio de perda da realidade, mas ele se faz a partir da transformação desta, da multiplicidade, das forças que produzem a diversidade do corpo. O bailarino, portanto, deixa-se acontecer, através do gesto e da dança, e incita as suas virtualidades a se atualizarem de variados modos estéticos. Cada coreografia, nesse sentido, surge como um novo convite às virtualidades, para que estas aconteçam de outras maneiras e ritmos e levem o corpo às aventuras e delírios do dançar.
Éric Alliez (1996) salienta que o plano de imanência compreende um tempo de coexistência entre virtual e atual, de criação e complexidade. Dessa maneira, qualquer elemento atual é povoado por uma névoa de imagens virtuais, as quais operaram sob um princípio de incerteza e de indeterminação, seguido de um movimento de criação. No plano de imanência, pode ocorrer uma dissolução do atual, que faz com que a potência das virtualidades ganhe mais consistência. É assim que o virtual cria, quando se atualiza, mas ele é, também, aquilo que se modifica e se transforma: um tempo de plasticidade e de invenção.

Conforme Deleuze (1992), o plano de imanência não é um conceito pensado ou pensável, mas a imagem do pensamento, a imagem que ele se dá do que significa pensar, fazer uso do pensamento, se orientar no pensamento.

Portanto, as potências imagéticas produzem o devir da imagem, pois um encontro de heterogêneos aciona uma nova vizinhança entre corpos e imagens. Um não muda menos que o outro e ambos tensionam os antigos estereótipos em relação à loucura. No Ballet Contágio, seguimos dançando e produzindo fotografias estéticas. Uma nova atmosfera vai sendo tecida por meio de ímãs e bifurcações. Em uma pequena cápsula de sonhos, os integrantes compõem um coletivo envolvente, ao abrir mão dos clichês e investir nas forças estéticas que atravessam o corpo e o transformam de múltiplos modos. Assim, propomos uma clínica que passa a cartografar tais movimentos e abrir-se ao tempo da invenção e reciprocidade. 


\section{Referências}

ALLIEZ, Eric. Deleuze: Filosofia Virtual. Tradução de Heloisa B. S. Rocha. São Paulo: Editora 34, 1996.

DELEUZE, Gilles. Em medio de Spinoza. 2. Ed. Buenos Aires: Cactus, 2008.

Crítica e Clínica. São Paulo: Editora 34, 1997.

Cinema 2. A Imagem-Tempo. São Paulo: Ed Brasiliense, 1990.

Cinema 1. A Imagem-Movimento. São Paulo: Ed Brasiliense, 1983.

DELEUZE, Gilles; GUATTARI, Félix. O que é a Filosofia? São Paulo: Editora 34, 1992.

Mil Platôs. Capitalismo e Esquizofrenia. V. 4. São Paulo: Editora 34, 1997.

FONSECA, Tania Mara Galli. A reforma psiquiátrica e a difícil reconciliação. In: FONSECA, Tania Mara Galli; ENGELMAN, Selda; PERRONE, Cláudia Maria (Orgs.). Rizomas da Reforma Psiquiátrica: a difícil reconciliação. Porto Alegre: Sulina/UFRGS, 2007.

VILELA, Eugenia. À contraluz, o testemunho. Uma linguagem entre silêncio e corpo. In: COSTA, Luciano Bedin da; FONSECA, Tania Mara Galli (Orgs.). Vidas do Fora: habitantes do silêncio. Porto Alegre: Editora da UFRGS, 2010.

YASUI, Silvio. CAPS: estratégia de produção de cuidado e de bons encontros. In: PINHEIRO, Roseni; GULJOR, Ana Paula; GOMES, Aluisio; MATTOS, Rubem Araújo de (Orgs.). Desinstitucionalização da saúde mental: contribuições para estudos avaliativos. Rio de Janeiro: CEPESC:IMS/LAPPIS: ABRASCO, 2007.

Submetido para avaliação em 06 de agosto de 2011.

Aprovado para publicação em 24 de agosto de 2013.

Vilene Moehlecke: Professora auxiliar da Universidade do Vale do Rio dos Sinos - São Leopoldo - RS - Brasil. E-mail: vilenemo@unisinos.br

Tania Mara Galli Fonseca: Universidade Federal do Rio Grande do Sul - Porto Alegre - RS - Brasil. E-mail: tfonseca@via-rs.net 